\title{
Chikura Sea: \\ A Marine Border Between Japan and Tang China
}

KoIDA Tomoko

Translated by Kristopher REEVES

$\mathrm{W}$

hat sort of conceptions did Japanese people living in the medieval period harbor regarding the borders of their own land? The popular military tale known as Soga monogatari 曽我物語 (Tale of the Soga Brothers, late $13^{\text {th }}$ century or somewhat later) contains an episode in which a retainer of Minamoto no Yoritomo 源頼朝 (1147-1199), first shogun of the Kamakura bakufu, sees an auspicious dream in which his master gains command over the entire country. ${ }^{1}$ It is in the second chapter of this work that this retainer very explicitly states the imagined boundaries of Japan: the land is bound to the east by Sotogahama 外浜, literally “outer bay,” and to the west by Kikaigashima 鬼界島, “Ogres’ Isle.” This delineation is repeated in another famous military tale entitled Genpei jösuiki 源平盛衰記 (Rise and Fall of the Minamoto and Taira Clans, 1247-1249) as well as the kōwakamai 幸若舞 play Yume awase 夢合せ (Portent of Dreams). Soga monogatari contains a second, more complete, reference to the borders of Japan: to the extreme east, in the region of Ōshū 奥州 (corresponding to what is now the northeastern region of Honshū) lies Sotohama; to the west lies Kikaigashima, the western bastion; to the south, along the southern seaboard, stands Mount Kumano; to the north, along the shores of Echigo 越後 (modern-day Nigata) stretches a raging sea (Cogan, ch. 9). Here, then, we are given a clear picture of how medieval Japanese people envisioned the borders of their land.

Aside from the aforementioned landmarks, another toponym, that of Chikura gaoki ちくらが沖, that is, Chikura Sea, appears often in medieval literature and the performative arts — in Muromachi tales and kōwaka lyrics, for example —as a marine border separating Japan from tang China. Seeing as how this particular toponym is used neither before nor after the medieval period, it follows that Chikura Sea represents an imagined border, the significance of which was unique to the

\footnotetext{
${ }^{1}$ For a complete English translation of this work, see Cogan, Thomas, trans., The Tale of the Soga Brothers. Tokyo: University of Tokyo Press, 1987.
} 


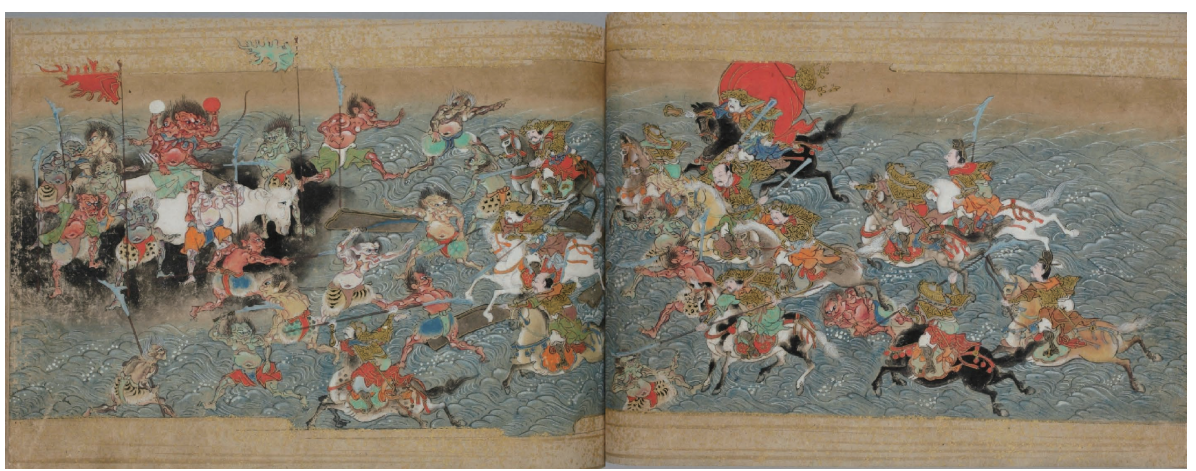

Figure 1. Illustration of the naval skirmish at Chikura Bay, from a manuscript of Taishokan held in the National Institute of Japanese Literature.

https://doi.org/10.20730/200016463

medieval period. Take, for example, the köwaka play Taishokan 大織冠 (The Great Woven (ap), which features a battle to gain possession of a precious jewel. Fujiwara no Kamatari 藤原鎌足 (614-669), fabled ancestor of the Fujiwara clan, was to be given this jewel as a present from the reigning emperor of the Tang empire. The ship bearing this gift is intercepted, however, by General Manko 万戸将軍 and his asura 阿修羅—-more-or-less demonic—soldiers, hired by the Dragon King 龍王 himself, to whom, we are told, this jewel originally belonged. General Banko and his men wait in ambush for the ship at none other than Chikura Sea, a place the playwright refers to revealingly as "the marine border between Japan and the Tang empire." A naval skirmish ensues, wherein all manner of supernatural and otherworldly combatants try their mettle against an army of mortal men, thus forming the climax of the first half of Taishokan. Every extant illustrated manuscript of this play contains a picture of this impressive scene (see Figure 1). Chikura Sea serves as the battleground between earthly and unearthly forces, just as it does, incidentally, in another kowaka play entitled Yuriwaka daijin 百合若大臣 (Minister Yurikawa).

In this second play, Minister Yuriwaka 百合若 is commanded to lead an army against a Mongolian general bent on invading Japan. While sailing from Tsukushi, in modern-day Kyushu, to one of the Korean kingdoms known in Japan as Kōrai 高麗 (K: Koryŏ), Minister Yuriwaka is intercepted by the Mongolian general, who, seeking to prevent his enemy from gaining the shore, confronts him in Chikura Sea. A prolonged and fierce naval battle is at last concluded in the minister's favor, though only after he has received divine aid from a number of native gods. A manuscript of Yuriwaka monogatari emaki 百合若物語絵巻 (Illustrated Tale of Minister Yuriwaka) currently stored in the Tokyo National Museum contains an illustration of this naval battle, wherein the Mongolian general, like General Banko and his demonic minions, as found in Taishokukan, is likewise depicted as an otherworldly fiend (Figure 2). Moreover, just as was the case with Taishokukan, Chikura Sea 


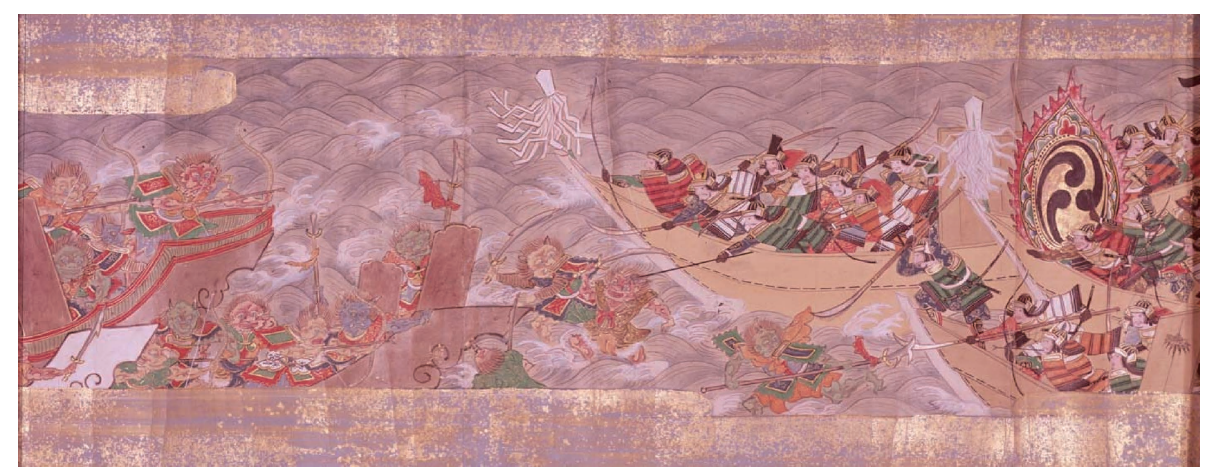

Figure 2. Illustration of the naval battle at Chikura Bay, from a manuscript of Yuriwaka monogatari emaki held in the Tokyo National Museum.

serves in Yuriwaka monogatari emaki, too, as a liminal sort of marine battleground between two forces, the one more-or-less familiar and wholly worldly, the otherhere represented by the Mongolian threat-foreign and otherworldly.

Chikura Sea, representing as it did a locus of contact between things worldly and otherworldly, came also to serve as the watery stage upon which various strange and fantastic creatures were wont to appear. In a Muromachi tale entitled Sumiyoshi no engi 住吉の縁起 (The Origin of Sumiyoshi Shrine), a Tang emperor, intent on invading Japan, sends the famous Chinese poet Bai Juyi 白居易 (often transliterated as Bo Juyi, 772-846) over to the archipelago in order to ascertain the intelligence of its inhabitants. Having reached Chikura Sea, Bai Juyi's vessel is hailed by an elderly fisherman who engages in a lively dialogue with the poet. Astonished at the level of erudition exhibited by this seemingly lowly fisherman, Bai Juyi concludes that the Japanese people must be among the most intelligent in the world. The Tang emperor, upon hearing this news, abandons all plans to invade Japan. We are informed that this fisherman was in fact an embodiment of none other than the god of Sumiyoshi Shrine, and that, no sooner had he disappeared than the sea began churning violently, followed by an appearance by the Dragon King, ruler of the waves.

There is a sermon ballad of the Edo period (sekkeyöbushi 説経節) by the name of Karukaya かるかや (Vines) in which the mother of Kūkai 空海 (774-835), portrayed here as the daughter of a Tang emperor, is sent away from her homeland in a dugout canoe on account of her apparently supremely despicable nature. Eventually she is washed up and rescued on the shores of Chikura Sea. In the kyogen 狂 言 play entitled Mechika 目近 (The Phony Fan), this same Chikura Sea is said to contain a miraculous rice paddy in which, if a man sows but a single seed, his yield of rice will increase ten-thousand-fold. Another kyogen play by the name of Jishaku 磁 石 (The Lodestone), contained in Kyōgenki 狂言記 (Record of Kyōgen Plays, 1660), a collection of kyogen scripts, has the spirit of the lodestone inhabiting a mountain located in Chikura Sea. All of this goes to demonstrate how Chikura Sea, in the 
medieval imagination, was seen as a place where divine and otherwise supernatural forces were wont to convene.

Jöruri monogatari 浄瑠璃物語 (A Tale of Lady Joruri, probably $15^{\text {th }}$ century), is a musical puppet-ballad depicting the love affair between the young general Minamoto no Yoshitsune 源義経 (1159-1189) and a courtesan who goes by the name Lady Jōruri 浄瑠璃姫. Significantly, the robe which Yoshitsune wears is described as being embroidered with a picture of Chikura Sea, "the marine border between Tang China and Japan," wherein two monkeys, one representing China, one Japan, bear their teeth at one another, each hoping to pass over the watery border into the other's territory. The Museum of Art (MOA) in Fukuoka contains a $17^{\text {th }}$-century manuscript of Joruri monogatari emaki in which Yoshitsune's robe sports two embroidered monkeys, facing off against each other over the sea, one with a red, the other with a white face. The same sort of description of Yoshitsune's robe can also be found in the kowwaka play Eboshi ori 烏帽子折 (The Courtier's Cap). It must be remembered that Yoshitsune is a man around whom all sorts of legends have been crowded: he is purported to have travelled to Öshū, the northeastern border of Honshū, where he visited not only the land of ogres and the realm of tengu 天 狗, long-nosed mountain goblins, but even descended into the depths of purgatory. It is only proper, therefore, that this man, a heroic figure able to traverse those borders between this and other worlds, should bear upon his back such a symbolically decorated robe.

Where exactly was this Chikura Sea supposed to be located? What is the significance of this toponym? The late writer and scholar of Japanese literature, Saigo Nobutsuna 西郷信綱 (1916-2008), has looked in some detail at the history of this toponym (“Kodaiteki uchū no ichi danmenzu” 古代的宇宙の一断面図 in Kodaijin to shi 古代人と死. Tokyo: Heibonsha, 1999). According to his investigations into the beliefs and rituals of ancient Japanese people, the two oldest historical works of Japan, namely, Kojiki 古事記 (Records of Matters of Antiquity, 712) and Nibon shoki 日本書紀 (Chronicle Documents of Japan, 720), contain references to something which might very well be related to the name of Chikura Sea. In a particular myth about Susanoo スサノタ, one of the more destructive gods amidst the ancient pantheon, we hear of an altar upon which the offerings of those wishing to be ritually purified are laid. This altar is known as the chikura no okito or chikura no okikura 千座の置座, literally, the altar of a thousand shelves, or offerings (chikura < chi one-thousand + kura shelf, platform, offering). In this context, says Saigō, the chikura altar serves as an embodiment of the land's collective defilement. He then concludes by averring that it was the Urabe, a clan of hereditary ritual masters serving at court, who gave the name to this bay, a bay which Saigō locates off the shores of Tsushima and Iki, two of Japan's westernmost outlaying islands (both of which currently fall under the jurisdiction of Nagasaki Prefecture). The Urabe 卜部 were based originally in these two islands-places associated with borders and border-crossings precisely in virtue of being located so close to the continent. These Urabe, being intimately involved with the aforementioned purification 
ritual, drew upon the liminal nature of the chikura altar, serving as it did as a kind of border between the world of men and the world of gods, and applied this name to the sea about their native islands. By bringing in considerations of ancient Japanese rituals, Saigō sought to explain the liminal nature of Chikura Sea, insofar as it served as a place where strange and supernatural creatures were thought to appear, interacted, and, at times, engage in fantastic warfare.

Unno Kazutaka 海野一隆 (1921-2006), a scholar of geography who specialized in the history of geography in Asia, located Chikura Sea in what the Engi shiki 延 喜式 (Procedures of the Engi Era, 927) refers to as Tōchika 遠值嘉, “the westernmost border of the land" ("Chikuragaoki: awasete Jishakuyama mo ちくらが 沖一合わせて磁石山も” in Tōyo chirigakushi kenkyū: Nihon ben 東洋地理学史研 究一日本篇. Osaka: Seibundō, 2005). This would correspond, he concludes, to the westernmost extremity of modern-day Fukuejima (likewise under the jurisdiction of Nagasaki Prefecture), one of a group of five islands lying yet further southwest of Tsushima and Iki. Finally, Unno suggests that the toponym Chikura ga oki, Chikura Sea, is an abbreviated form of what was originally Chikaura no oki, namely, the offing near Chika Bay. That is, the first $a$ in chika-ura (Chika Bay) was dropped to produce chikura. Whatever the supposed location of Chikura Sea might be, it remains certain that this place, as it appears in Muromachi tales and kowaka plays, represented to the medieval Japanese imagination a western marine border, the nature of which was different than Kikaigashima, Ogre's Isle, also thought to lie to the west of Japan. 